\title{
Field test of active night cooling supplied by district cooling in three commercial buildings
}

\author{
Maria Jangsten $^{1 *}$, Torbjörn Lindholm ${ }^{1}$, and Jan-Olof Dalenbäck ${ }^{1}$ \\ ${ }^{1}$ Division of Building Services Engineering, Department of Architecture and Civil Engineering, Chalmers University of Technology, \\ SE-412 96 Gothenburg, Sweden
}

\begin{abstract}
Several previous studies have investigated active night cooling strategies to reduce the peak cooling load in buildings, primarily by precooling the building by the ventilation air during the night. In this study, active night cooling is supplied by the use of district cooling, mainly for cooling buildings by hydronic cooling systems, such as chilled beam or fan coil systems, but potentially also to cool the ventilation air if the outdoor air temperature is above the supply air temperature setpoint. A field test with active night cooling by district cooling was conducted during the summer of 2020 in three commercial buildings located in Gothenburg, Sweden. The active night cooling strategy was implemented by changing the time schedule operation of the buildings' chilled beam systems to twenty-four hours per day for the first half of the summer and changing back to regular time schedules for the second half. The results showed that active night cooling failed to reduce the hourly maximum cooling power. However, the peak cooling load, corresponding to the 100 hours with the highest cooling power, was reduced with $6.5 \%$ for one of the buildings. Active night cooling also reduced the daytime energy usage between 0.7 and $4.6 \%$. The field test demonstrated that some buildings and associated cooling systems are more compatible for active night cooling than others. The test also showed it was possible to achieve some cooling power and energy reductions with simple measures. However, providing active night cooling supplied by district cooling will cause additional costs for the building owners unless it is incentivized by the district cooling provider.
\end{abstract}

\section{Introduction}

The global energy use to supply buildings with space cooling is expected to increase threefold by the year 2050 compared to 2016 [1]. To avoid such a drastic increase, district cooling (DC) is a less primary energy intensive alternative compared to building individual airconditioners and chillers. In district cooling systems, chilled water is generated centrally and distributed in underground pipes to connected buildings. If buildings in a city are connected to the district cooling system, their individual cooling demands become aggregated and distributed as a result of different business types and occupancy schedules among the buildings [2].

Despite benefits with aggregated cooling demands on a city level, the district cooling provider has to maintain a sufficient amount of installed cooling capacity to supply the buildings during peak cooling load conditions. This often accompanies large investment and maintenance costs for peak load chillers that only need to operate for short periods each year [3]. One measure to reduce the number of peak chiller units is to incorporate a central thermal energy storage, such as a chilled water tank, charged during the night and discharged during the day [4], [5].

A supplement or possible alternative, to a central thermal energy storage is to utilize the connected buildings for thermal energy storage. This can be achieved in many different ways, for example by incorporating phase change materials (PCM) in the buildings [6] and utilizing radiative cooling systems such as thermally activated building systems [7]-[9]. Another measure, which is simple to implement in existing buildings, is to supply active cooling during the night, thereby using the building's structure for thermal energy storage. This measure has been researched dating back to the late 80 's and requires minimal investment costs and only an adjustment of the existing HVAC system's control strategy.

"Night cooling" can refer to a multitude of different strategies and definitions, however all with the goal to cool a building during the night and thereby reducing the peak cooling load during the day by using the cold energy stored in the building structure. Night cooling strategies can for clarification be divided into three categories: 1) active night cooling (also referred to in the literature as precooling or mechanical precooling using ventilation air), 2) passive night cooling (using the prevailing outdoor temperature for cooling with the ventilation system, also called night ventilation in the literature) and 3) hybrid night cooling (a combination of both active and passive night cooling strategies as defined above). Active night cooling is defined as using ordinary (most often chiller) generated cooling in the building at a predetermined

\footnotetext{
* Corresponding author: maria.jangsten@chalmers.se
} 
setpoint of the air or the chilled water [10]. Passive night cooling means to supply night ventilation to the building using the lower outdoor air temperature to cool the building. This is also referred to as "free cooling" due to the absence of chiller or other forms of generated cooling [11]. A multitude of previous studies have investigated the aforementioned night cooling strategies for existing buildings, and the focus of this study is the active night cooling strategy.

\subsection{Literature review}

Active night cooling has previously been evaluated by means of dynamic building model simulations, primarily for buildings located in warm climates. For example, simulations of a building in a subtropical climate, which showed that a $20 \%$ reduction of the peak cooling load was possible [12]. Similarly, a simplified active night cooling strategy by changing the temperature settings during the unoccupied period, was simulated in a commercial building in Tunisia, yielding a 10-25\% electrical peak demand reduction during the summer months [13]. In another study, $10-20 \%$ of the peak cooling load was reduced during the day by allowing the indoor air temperature to decrease $2{ }^{\circ} \mathrm{C}$ during the night [14]. Simulations of an office building with two different active night cooling strategies accomplished peak cooling load reductions by up to $50 \%$, compared to turning the HVAC system off at night [15]. By developing an evaluation tool for active night cooling control strategies, a $40 \%$ reduction in total cooling costs was obtained, compared to regular night setup control [16].

According to Keeney and Braun [17], the control strategies of active night cooling have to be adapted to its application, for example by tailoring two simplified optimal control approaches to site-specific control [17]. Henze et al. [18] reached electricity cost savings of $13 \%$ by optimal active night cooling control, however at the expense of a 1-3\% increased energy use by the chiller and the fan. Morris et al. [19] showed through simulations and an experiment of two different optimal control strategies that the peak cooling load could be reduced with $40 \%$. Lee and Braun [20] reached a 30\% peak cooling load reduction with a building model of a small commercial building and an optimal control strategy. The control strategy incorporated a demand-limiting strategy which allowed the indoor temperatures to increase according to a peak cooling load trajectory.

Based on these previous studies, it is evident that active night cooling has the potential of successfully reducing the building peak cooling load and saving energy and costs. However, the wide range of results suggest the amount of savings strongly depend on the investigated building, the HVAC system, the associated control strategy and its optimization but also on the ambient climate at the building location and the inherent building model assumptions. This makes the implementation of active night cooling for a specific building complex and resource demanding as well as the outcomes are uncertain.
In addition to investigation active night cooling by means of simulation and optimization, a number of laboratory and field tests have also been conducted. Such studies are necessary to increase the applied knowledge for further potential implementation. In a laboratory test carried out in a test chamber, the peak cooling demand was reduced with $35 \%$, however with an increased energy usage of $12 \%$ [21]. Another laboratory test using one zone in a commercial building, showed that a small cooling load reduction could be achieved by simple strategies. The strategies were for example keeping the cooling system in operation during the unoccupied period and allowing the room temperature to increase during the occupied period [22].

One of the first field tests on active night cooling was a conducted in 1989 on two of the 37 floors of an office building located in Florida. The two floors were precooled during the night and on weekends during two separate test periods in June and September. The test resulted in an $18 \%$ reduction in used cooling energy during the day, but no reduction of the peak cooling demand [23]. During the first test period, the occupants complained on the indoor thermal comfort on Monday morning. The extensive weekend precooling was therefore eliminated for the second test period by limiting the indoor temperature to no less than $19^{\circ} \mathrm{C}$. In a field test for an elementary school in Colorado the minimum indoor temperature setpoint for active night cooling was set to $21^{\circ} \mathrm{C}$ to avoid thermal comfort complaints. However, active night cooling was shown not to be effective for this particular building [24].

Another field test was carried out in an office building in Chicago which resulted in a $25 \%$ potential cooling capacity reduction [25]. A field test at Iowa Energy Center was performed to test active night cooling, however, in a building not ideal for the utilization of building structure thermal energy storage. Despite this, it was shown that the peak load was reduced by $9 \%$ [26]. Later on, another field test was conducted at the same facility to test a demandlimiting control strategy. The control strategy resulted in more than $30 \%$ peak cooling load reductions compared to a conventional control strategy with a fixed but also higher indoor air temperature setpoint for the nighttime operation [27].

\subsubsection{Passive \& hybrid night cooling strategies}

Even though several previous studies on active night cooling have been carried out, passive night cooling (night ventilation) is a more well-established and extensively implemented night cooling strategy for commercial buildings [28]. Another night cooling strategy that has been researched to some extent is a hybrid between passive and active night cooling. It has been studied by means of simulations of an office building located south of Gothenburg, Sweden [29] as well as by an experiment and simulations on an institutional building in Freiburg, Germany [30]. Additionally, it has been evaluated for a commercial building in Montreal [31], where it was shown that night ventilation had the largest potential for thermal mass storage when the supply air setpoint was $12{ }^{\circ} \mathrm{C}$ compared to 15 and $18{ }^{\circ} \mathrm{C}$. This means 
that cooling may have to be supplied by chillers as opposed to solely relying on the ambient outdoor temperature.

Braun [32] showed that a hybrid night cooling strategy can reduce the energy cost with $10-50 \%$ and decrease the peak electrical use by $10-35 \%$. Kolokotroni and Aronis [33] concluded that a hybrid night cooling strategy can save energy if active night cooling is used to assist the passive night cooling. Furthermore, the hybrid night cooling strategy was also simulated in two buildings located in Stockholm, with HVAC systems composed of both ventilation and hydronic cooling systems supplied by district cooling [34]. The most optimal result was obtained with the ventilation system operating twentyfour hours per day, along with a $1{ }^{\circ} \mathrm{C}$ reduction of the supply air temperature during the night. Additionally, it was suggested that more energy could be stored in the building if district cooling was actively used during the night alongside free cooling from the outdoor air.

\subsubsection{Potential for active night cooling}

Based on the literature review there is a potential for successful use of active night cooling in commercial buildings. However, this potential is difficult to evaluate and depends on several different factors. For example, it depends on the availability of information about the building's construction and storage capability, the building's HVAC system design and components, the occupancy schedule and control strategy, the ambient climate at the building location and also the price model of the energy provider [10], [32]. For this reason, implementation of active night cooling can become complicated while the uncertainty around beneficial outcomes remain [26]. This could be a reason there is still only a few applications of active night cooling in existing buildings.

For active night cooling to be advantageous, economic incentives are essential. Active night cooling can be economically beneficial when the energy provider charges according to a peak and off-peak demand schedule [14]. However, improper deployment of active night cooling can result in greater energy use and higher costs [26]. For buildings with hydronic cooling systems supplied by district cooling it may not possible to use passive night cooling when the outdoor temperature allows, and the utilization of the building structure for cold energy storage will cause additional costs. Therefore, if active night cooling is proven to be successful for buildings with hydronic cooling systems, incentives by the district cooling provider may be needed for active night cooling to be an attractive control strategy. It has previously been concluded that an initial field test can provide a foundation for evaluation of economic incentives and further research, such as control optimization [26], [27]. Despite several field tests conducted on active night cooling in commercial buildings, there are no prior field tests on active night cooling in commercial buildings with hydronic cooling systems supplied by district cooling.

\subsection{Aim of study}

The aim of this study is therefore to conduct a field test with active night cooling in three commercial buildings equipped with hydronic cooling systems supplied by district cooling. The effectiveness of active night cooling to reduce the hourly maximum cooling power and the peak cooling loads of the buildings will be evaluated along with the impact on energy use, indoor comfort (air temperatures) and costs. The objective of the field test is a quick implementation of the active night cooling strategy by means of simple adjustments of the control strategy without any investments nor in-depth knowledge about the building parameters for simulations or control optimization. The field test is conducted in collaboration with the district cooling provider and the building owner to evaluate the economic incentives.

\section{Building descriptions and field test setup}

The buildings investigated in this field test are three commercial buildings mainly with offices but also some retail spaces. See Table 1 for detailed information along with construction and renovation years. The buildings are located in the downtown area of Gothenburg, Sweden.

Table 1. Information about the buildings.

\begin{tabular}{|c|c|c|c|}
\hline & Building 1 & Building 2 & Building 3 \\
\hline $\begin{array}{l}\text { Number of } \\
\text { floors }\end{array}$ & 7 & 8 & 4 \\
\hline $\begin{array}{c}\text { Area total } \\
{\left[\mathrm{m}^{2}\right]}\end{array}$ & 8814 & 9270 & 10345 \\
\hline $\begin{array}{l}\text { Area office } \\
\text { space }\left[\mathrm{m}^{2}\right]\end{array}$ & 5157 & 7789 & 9769 \\
\hline $\begin{array}{c}\text { Area retail } \\
{\left[\mathrm{m}^{2}\right]}\end{array}$ & 3657 & 1481 & $\begin{array}{c}576 \\
\text { (restaurant) }\end{array}$ \\
\hline $\begin{array}{c}\text { Construction } \\
\text { year }\end{array}$ & 1939 & 1844 & mid-1980's \\
\hline $\begin{array}{c}\text { Renovation } \\
\text { year }\end{array}$ & 1996 & $\begin{array}{c}1930 \& \\
2009 \\
\end{array}$ & NA \\
\hline $\begin{array}{l}\text { Building } \\
\text { certification }\end{array}$ & $\begin{array}{c}\text { LEED } \\
\text { Silver, } 2015\end{array}$ & $\begin{array}{l}\text { LEED Gold, } \\
2015\end{array}$ & $\begin{array}{l}\text { LEED Gold, } \\
2019\end{array}$ \\
\hline
\end{tabular}

The buildings' HVAC systems are composed of a combination of air-based and hydronic cooling systems, outlined in Figure 1. The buildings' chilled water systems are supplied by the district cooling system in Gothenburg. Although the successful implementation of active night cooling is dependent on several additional building parameters, for example effective thermal capacitance for energy storage [15], the detailed assessment involving such parameters was outside the scope of this study, mainly due to the complexity of acquirement. Instead, practical aspects such as ability of altering the time schedule control and number of chilled beam systems were considered when choosing the test objects. 


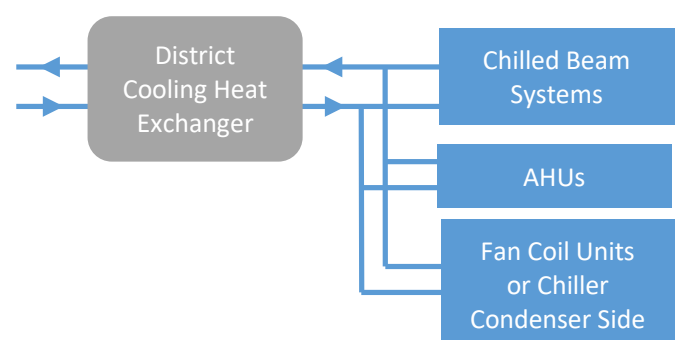

Figure 1. Schematic of the buildings' chilled water system and HVAC components supplied by district cooling.

Building number one has a concrete core and slab, concrete façades with plaster finish and windows and a tar paper roof. The interior ceilings are suspended, and the interior floors have a mix of coatings such as parquet and textile carpets. The interior walls are primarily made of gypsum boards as well as some plaster walls. The chilled water system is outlined in Figure 1 and for building one it serves three air handling units (AHUs), six chilled beam systems with passive chilled beams and eight fan coils units. The chilled water system is controlled as per the following strategies: 1) the outdoor temperature determines the chilled water supply temperature setpoint according to a curve based on the characteristics of the building; 2) the peak power demand is restricted dependent on a fixed value to limit the power during peak load operation; 3) five different time schedules for the operation time of the chilled water system based on outdoor temperature and occupancy. The ventilation system operates as specified by time schedules based on occupancy. The room temperature setpoint for cooling is between 21.5 and $22{ }^{\circ} \mathrm{C}$ depending on the room.

Building number two consists of several adjacent buildings, connected into one large building body. It has a concrete core and slab and concrete façades with plaster finish and windows. The interior ceilings are suspended, the interior floors are mainly covered with linoleum and the interior walls and partitions are made of gypsum boards. The chilled water system in building two serves five AHUs, three fan coil units and two chilled beam systems. The chilled beam systems only serve parts of floor four and floors seven and eight and consist of active chilled beams. The control strategy of the chilled water system is based on 1) a fixed chilled water supply temperature setpoint; 2) peak power demand restriction according to a fixed value; 3 ) five different time schedules based on outdoor temperature and occupancy. The ventilation system operates as specified by time schedules based on occupancy. The room temperature setpoint for cooling is between 22 and $23{ }^{\circ} \mathrm{C}$ depending on the room.

Building number three is made of a concrete core and slab, curtain wall façades with large windows and chromed steel between the floors along with a tin roof. The majority of the interior ceilings are suspended, the interior floors are covered with linoleum carpet and the interior walls are primarily made of gypsum boards. The chilled water system supplies nine AHUs and five chilled beam systems serving different parts of the building. The chilled beams have ducted supply air but are of an older type which can be regarded as passive. The chilled water system also cools the condenser side of an in-building chiller. The control strategy is based on 1) linear adjustment of the chilled water supply temperature based on two outdoor temperatures and 2) on/off operation based on predetermined start and stop times according to occupancy. The ventilation system is regulated as specified by time schedules based on occupancy with the air flow rates being compensated based on the outdoor temperature. The room temperature setpoint for cooling is between 22 and $23.5^{\circ} \mathrm{C}$ depending on the room.

\subsection{Field test setup}

Active night cooling $(\mathrm{T})$ was tested for the first half of the summer of 2020 and the second half was used as a reference period (R), with operation back to normal control strategies. In Table 2, the duration of each period and building can be seen. The reference period was adjusted to start about 2.5 weeks after the test ended so that both test and reference periods had the same length in time and similar outdoor temperatures. Since the field test took place during the Covid-19 pandemic, the number of building occupants were expected to be lower than normal during both test and reference periods.

Table 2. Duration of test period and reference period for each building.

\begin{tabular}{|c|c|c|c|}
\hline & Building 1 & Building 2 & Building 3 \\
\hline $\begin{array}{c}\text { T: Active } \\
\text { night cooling } \\
\text { test period }\end{array}$ & $\begin{array}{c}1^{\text {st }} \text { of Jun to } \\
9^{\text {th }} \text { of Jul }\end{array}$ & $\begin{array}{c}1^{\text {st }} \text { of Jun to } \\
7^{\text {th }} \text { of Jul }\end{array}$ & $\begin{array}{c}1^{\text {st }} \text { of Jun to } \\
9^{\text {th }} \text { of Jul }\end{array}$ \\
\hline $\begin{array}{c}\text { R: Reference } \\
\text { period }\end{array}$ & $\begin{array}{c}28^{\text {th }} \text { of Jul } \\
\text { to } 4^{\text {th }} \text { of } \\
\text { Sept }\end{array}$ & $\begin{array}{c}27^{\text {th }} \text { of Jul } \\
\text { to } 1^{\text {st }} \text { of } \\
\text { Sept }\end{array}$ & $\begin{array}{c}27^{\text {th }} \text { of Jul } \\
\text { to } 3^{\text {rd }} \text { of } \\
\text { Sept }\end{array}$ \\
\hline $\begin{array}{c}\text { Hours per } \\
\text { period }\end{array}$ & 936 & 880 & 921 \\
\hline
\end{tabular}

As described in the previous section, each building's chilled water system control strategy comprises different components. To test active night cooling, the time schedule component of the chilled water system control strategy was changed to remain in operation twenty-four hours per day. For the reference period, the time schedule operation was changed back to regular schedules, which means that the chilled water systems typically turn off during nights and weekends, unless the outdoor temperature control component regulates the system to remain in operation. During the active night cooling test, the ventilation time schedules for the three buildings remained unchanged.

Although concluded beneficial in previous studies [14], [21], [27], no alterations to the supply air temperature setpoint was done during the active night cooling test, primarily due to the ventilation system not being part of the tested active night cooling control strategy. The room air temperature setpoints for cooling were not altered between test and reference period, nor were the chilled water temperature setpoints. The peak power demand restriction (where applicable) remained in effect during the test. 


\subsection{Data collection}

The data used to evaluate active night cooling was collected from the district cooling plant, the district cooling meters located in the substation of each building and the buildings' Supervisory and Data Acquisition (SCADA) systems, see Table 3.

Table 3. Data collection for evaluation of active night cooling.

\begin{tabular}{|c|c|c|}
\hline Data type & Collected from & $\begin{array}{c}\text { Frequency } \\
\text { acquisition }\end{array}$ \\
\hline $\begin{array}{c}\text { Outdoor } \\
\text { temperature }\end{array}$ & District cooling plant & Hourly \\
\hline $\begin{array}{c}\text { Cooling power, } \\
\text { primary flow, } \\
\text { primary delta-T }\end{array}$ & $\begin{array}{c}\text { District cooling meter on } \\
\text { primary side of building } \\
\text { substation heat } \\
\text { exchanger }\end{array}$ & Hourly \\
\hline $\begin{array}{c}\text { Indoor air } \\
\text { temperatures }\end{array}$ & $\begin{array}{c}\text { Building SCADA } \\
\text { system }\end{array}$ & Hourly \\
\hline $\begin{array}{c}\text { Chilled water } \\
\text { supply } \\
\text { temperatures }\end{array}$ & $\begin{array}{c}\text { Building SCADA } \\
\text { system }\end{array}$ & Hourly \\
\hline
\end{tabular}

\section{Results and discussion}

The outdoor temperatures during test and reference periods can be seen in Figure 2. The data was obtained from the district cooling plant to avoid local variations between the buildings' outdoor temperature sensors. The two periods proved to be quite similar in terms of outdoor temperatures with the test period on average having an outdoor temperature $0.25{ }^{\circ} \mathrm{C}$ lower than the reference period.

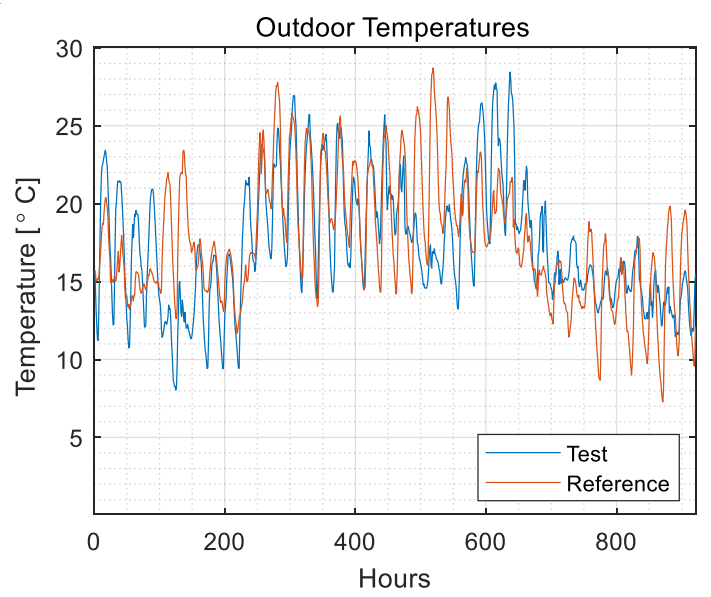

Figure 2. Outdoor temperatures during test period and reference period based on hourly data.

In Table 4, the hourly maximum cooling power, energy use, average chilled water temperatures supplied to the chilled beam systems and indoor air temperatures can be seen for each building and period. It is evident that the hourly maximum cooling power occurred during the test with active night cooling (except for building three), which shows that the active night cooling strategy did not succeed in reducing the hourly maximum cooling power, similar to the results in [23]. It can also be seen in Table 4 that the total cooling energy usage was between 1.7 and $5.3 \%$ higher during the active night cooling test compared to the reference period, which was expected and consistent with previous studies [18] and [21]. However, when investigating daytime and nighttime energy usage separately, it can be seen that the daytime energy usage was $4.6 \%$ and $0.7 \%$ lower for buildings one and three during the test period, something which was also found in [23], although the savings obtained in this study were notably smaller. In sections 3.1 and 3.3 a more detailed analysis of the results from daytime and nighttime operation can be found.

Table 4. Results from test period and reference period for each building.

\begin{tabular}{|c|c|c|c|c|c|c|}
\hline & \multicolumn{2}{|c|}{ Building 1 } & \multicolumn{2}{c|}{ Building 2 } & \multicolumn{2}{c|}{ Building 3 } \\
\hline Period: & $\mathbf{T}$ & $\mathbf{R}$ & $\mathbf{T}$ & $\mathbf{R}$ & $\mathbf{T}$ & $\mathbf{R}$ \\
\hline $\begin{array}{c}\text { Power, } \\
\text { maximum } \\
{[\mathrm{kW}]}\end{array}$ & 182 & 171 & 292 & 249 & 231 & 232 \\
\hline $\begin{array}{c}\text { Energy, } \\
\text { total } \\
{[\mathrm{MWh}]}\end{array}$ & 71.4 & 68.2 & 34.8 & 34.4 & 75.4 & 71.6 \\
\hline $\begin{array}{c}\text { Energy, } \\
\text { total } \\
{\left[\mathrm{kWh} / \mathrm{m}^{2}\right]}\end{array}$ & 8.1 & 7.7 & 3.8 & 3.7 & 7.3 & 6.9 \\
\hline $\begin{array}{c}\text { Energy, } \\
\text { daytime } \\
{[\mathrm{MWh}]}\end{array}$ & 50.8 & 53.3 & 31.3 & 31.2 & 53.0 & 53.3 \\
\hline $\begin{array}{c}\text { Energy, } \\
\text { nighttime } \\
{[\mathrm{MWh}]}\end{array}$ & 20.6 & 14.9 & 3.5 & 3.2 & 22.4 & 18.3 \\
\hline $\begin{array}{c}\text { Avg. } \\
\mathrm{CHWST}^{1} \\
{\left[{ }^{\circ} \mathrm{C}\right]}\end{array}$ & 15.7 & 17.9 & 15.9 & 18.6 & 15.2 & 16.1 \\
\hline $\begin{array}{c}\text { Avg. IAT } \\
{\left[{ }^{\circ} \mathrm{C}\right]}\end{array}$ & 23.8 & 25.0 & 23.3 & 23.4 & 24.6 & 24.8 \\
\hline
\end{tabular}

${ }^{1}$ CHWST $=$ Chilled Water Supply Temperature.

${ }^{2}$ IAT=Indoor Air Temperature, averages based on data from available room temperature sensors, for all hours with outdoor temperatures $\geq 22^{\circ} \mathrm{C}$.

Additionally, based on information from Table 4, the average chilled water supply temperature to the chilled beam systems was lower for the test period, as expected. The average indoor air temperatures are reported for all hours with outdoor temperatures $\geq 22{ }^{\circ} \mathrm{C}$ and were almost the same for both periods for buildings two and three. It was only a significant difference between the two periods for building one, with an average of $1.2{ }^{\circ} \mathrm{C}$ lower indoor air temperatures with active night cooling.

\subsection{Cooling loads}

Since there are several different factors affecting the cooling load of the building (such as solar radiation and outdoor temperature, as well as weather-independent process cooling loads and occupancy), this analysis only compares the outcome of active night cooling with the reference case, and it is outside the scope of this study to analyze the different cooling load factors and their impact in detail. In Figure 3, the day and night cooling load duration curves for each period and buildings are provided (day- and nighttime have been defined as per the characteristics of building one, see section 3.3). 
For buildings one and three it is apparent that some cooling energy was stored during low load hours at the right end of the night duration curves, since the nighttime cooling load was much lower during the reference period compared to the test period. For building two, no cooling energy was stored since the difference between the nighttime duration curves for the test and reference period is very small. This could be due to several factors but primarily because the chilled beam systems only served a small fraction of the building's total cooling demand. Moreover, the chilled beams were of the active type with ducted supply air. Since it was only the chilled water system control strategy that was altered during test period, the chilled beams were not supplied with primary air twenty-four hours, but only chilled water.
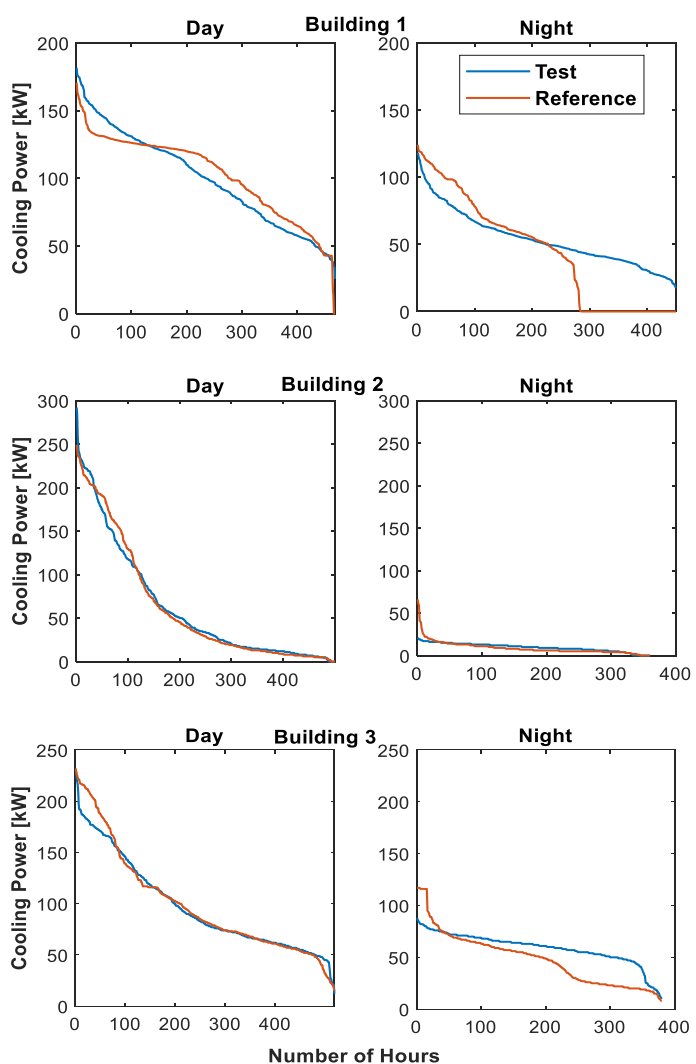

Figure 3. Cooling load duration curves for day and night, test and reference period and each building.

For hours 0 to approximately 100 in the daytime diagrams of Figure 3, which represent the peak cooling period, the opposite behaviors for buildings one and three can be observed. For building three, active night cooling reduced the peak cooling load with $6.5 \%$, equivalent to 12 $\mathrm{kW}$, compared to the reference period, whereas for building one the peak cooling load was $13 \mathrm{~kW}$ or $9.5 \%$ larger during the active night cooling test compared to the reference period. The reason to this was the peak power restriction control feature (which limits the peak demand according to a fixed value), which was out of order for the majority of the test period. It was repaired before the reference period started. This means a power restriction has a larger effect in terms of peak cooling load reduction than the active night cooling has, at least for building one. However, the control system of building three did not have the power restriction feature and a combination of both active night cooling and power demand restriction could be beneficial, something which has also been shown in [20] and [27].

Another observation that can be made from the duration curves for building one in Figure 3 is the medium load cooling demand reduction achieved by active night cooling. The medium cooling load is represented approximately between hours 130 and 450 for daytime operation and hours 0 to 200 for nighttime operation. It was $10 \%$ lower during the active night cooling period compared to the reference period.

Moreover, with active night cooling the ramp up morning peak cooling power was avoided for building one, when the outdoor temperature was between 10 and $15{ }^{\circ} \mathrm{C}$, see Figure 4. For the reference period the cooling system was turned off during most nights and turned back on in the morning, causing the cooling power to jump from 0 to about $100 \mathrm{~kW}$ in one hour. This peak occurred at 5:00 during weekdays and 9:00 during weekends. The morning peaks with active night cooling was $41 \%$ lower compared to the reference period based on data from six mornings, with outdoor temperatures being within $2{ }^{\circ} \mathrm{C}$. When the outdoor temperature was larger than $15^{\circ} \mathrm{C}$, the chilled water system remained in operation during the night for the reference period as well, and the morning peaks were not observed. Similar trends of morning peak cooling power reductions with active night cooling were not seen for buildings two and three.

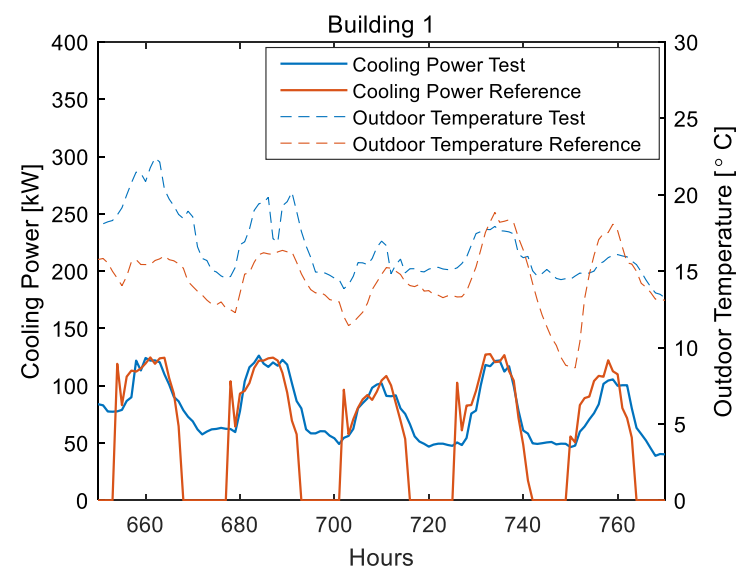

Figure 4. Building 1 cooling power and outdoor temperature for the active night cooling period and the reference period, selected for five days which show the morning peak cooling power occurring during the reference period.

\subsection{Indoor air temperatures}

The indoor air temperatures presented in Figure 5 are based on hourly averages of the data from available room temperature sensors, in total 4 different room temperature sensors for building one, 3 for building two and 2 for building three. The diagrams in Figure 5 are arranged so that the difference between the test and the reference period can be seen for each building. It is evident that the indoor air temperatures have been lower during the test with active night cooling compared to the reference period for building one but have been less affected for buildings two and three. Moreover, the range of indoor air temperatures of $20-26.4{ }^{\circ} \mathrm{C}$ has been quite large for 
building one compared to the other two buildings, which is also necessary for cooling energy to be stored. The lower end of this range also indicates that the indoor air temperature has been lower than the room temperature setpoint for cooling during the test period in building one, whereas the indoor air temperatures for buildings two and three have mostly been higher than the room air temperature setpoints, regardless of test or reference period.

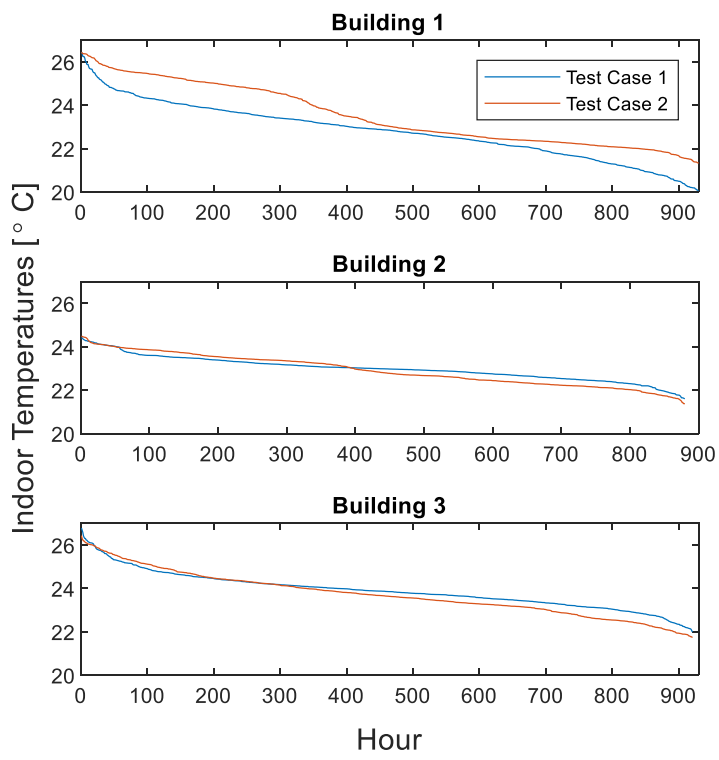

Figure 5. Indoor air temperatures during the test period with active night cooling and the reference period for each building.

What could also be seen in Figure 5 is that indoor air temperatures greater than $25^{\circ} \mathrm{C}$ occur very few hours. To limit the peak cooing power it could for this reason be beneficial to allow the indoor air temperature to increase further, for example during the afternoons.

An important aspect regarding the indoor air temperatures when utilizing active night cooling is to avoid a too low indoor air temperature in the morning, which has been reported as an occupant issue in a previous active night cooling test [23]. According to Figure 5, building one had the lowest indoor air temperatures $\left(<21.5^{\circ} \mathrm{C}\right)$. By further investigation, it was found that the indoor air temperature decreased during the night for the test period, but in the order of $1-1.5^{\circ} \mathrm{C}$ compared to the previous highest daytime indoor air temperature. The lowest indoor air temperature of around $20{ }^{\circ} \mathrm{C}$ was reached when the outdoor temperature was between 11 and $15^{\circ} \mathrm{C}$, but nevertheless the previous highest indoor air temperature was approximately $1-1.5^{\circ} \mathrm{C}$ higher, as can be seen in Figure 6.

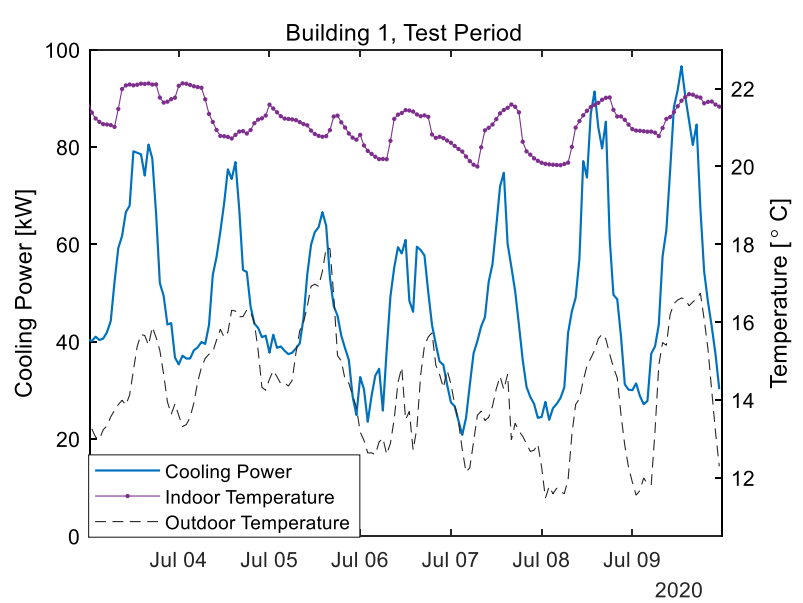

Figure 6. Example of cooling power, indoor air temperature and outdoor temperature for building 1 during one week of the test period.

\subsection{Evaluation of economic incentives}

The active night cooling strategy requires the building's chilled water system to remain in operation during the night which ultimately means the total energy usage will increase. To evaluate economic incentives, nighttime data was analyzed separately and can be seen in Table 5. Since the nighttime hours are dependent on the building's occupancy schedule, they will differ for each building. For this analysis, nighttime has been defined based on the operational characteristics of building one and include the hours from 19:00 until 04:59 (excluding data recorded for 05:00).

Table 5. Results for nighttime operation between 19:00 and 04:59 for the test and reference periods for each building.

\begin{tabular}{|c|c|c|c|c|c|c|}
\hline $\begin{array}{c}\text { Night } \\
\text { data }\end{array}$ & \multicolumn{2}{|c|}{ Building 1 } & \multicolumn{2}{c|}{ Building 2 } & \multicolumn{2}{c|}{ Building 3 } \\
\hline Period: & T & R & T & R & T & R \\
\hline $\begin{array}{c}\text { Energy } \\
{[\mathrm{MWh}]}\end{array}$ & 20.6 & 14.9 & 3.5 & 3.2 & 22.4 & 18.3 \\
\hline $\begin{array}{c}\text { Energy } \\
{[\mathrm{kWh}} \\
\left./ \mathrm{m}^{2}\right]\end{array}$ & 2.3 & 1.7 & 0.4 & 0.3 & 2.2 & 1.8 \\
\hline $\begin{array}{c}\text { Primary } \\
\text { flow } \\
{\left[\mathrm{m}^{3}\right]}\end{array}$ & 2720 & 2007 & 388 & 383 & 2894 & 2349 \\
\hline $\begin{array}{c}\text { Primary } \\
\text { delta-T } \\
{\left[{ }^{\circ} \mathrm{C}\right]}\end{array}$ & 6.6 & 6.2 & 7.9 & 7.4 & 6.7 & 6.4 \\
\hline
\end{tabular}

${ }^{1}$ Excluding delta-T recordings when the primary flow is zero.

The district cooling price model consist of three components: energy, power and flow. The energy price is a fixed price per MWh depending on the month of the year, the power price is based on the highest power used for the previous year and the flow price is fixed per $\mathrm{m}^{3}$ utilized. Each of these components may be affected when using active night cooling.

Based on data in Table 5, the energy use during the night for the test period was greater for all three buildings. Assuming a fictive energy price during the summer months, the discount on the energy component of the price 
model needs to be $27.5 \%$ for building one, $8.3 \%$ for building two and $18.5 \%$ for building three to compensate for the increased energy costs during the active night cooling test.

The charge for cooling power is determined based on the building's previous year's maximum power demand and follows a bracket pricing model. Depending on the proximity of a lower cost bracket, the hourly maximum cooling power may have to be significantly reduced with active night cooling in order to drop down to a lower cost bracket. This is something none of the buildings in this field test achieved. However, other control strategies such as peak power demand restrictions may be more effective in achieving this, either with or without the addition of active night cooling control.

The third component of the price model is the primary district cooling water flow through the heat exchanger in the building's substation. According to Table 5, the primary chilled water flow during nights for the test period was higher for all three buildings. However, an increased flow could also be due to a poor primary delta$\mathrm{T}$ and as can be seen in Table 5 , the delta-T is between 0.3 and $0.5^{\circ} \mathrm{C}$ lower during the reference period. For this reason, the flow rate has been adjusted based on the nighttime delta-T for the active test period for comparison purposes. When considering this adjustment along with a fictive price for the flow charge, the discount on the flow component needs to be $22 \%$ and $16 \%$ for buildings one and three respectively, to compensate for the increased cost. For building two the discount is not applicable since the flow rate, when adjusting for a lower delta-T, resulted in a higher flow rate for the reference period compared to the test period.

If a nighttime flow rate price discount is to be offered for buildings with active night cooling it is important to consider other reasons to a non-zero chilled water flow rate during the night. Despite the building being unoccupied, the chilled water control system may request cooling during the night if other control components, such as the outdoor temperature, reach certain setpoints. In Figure 7, it can for example be seen that the primary chilled water flow is larger than zero for several nights in the reference period as well.

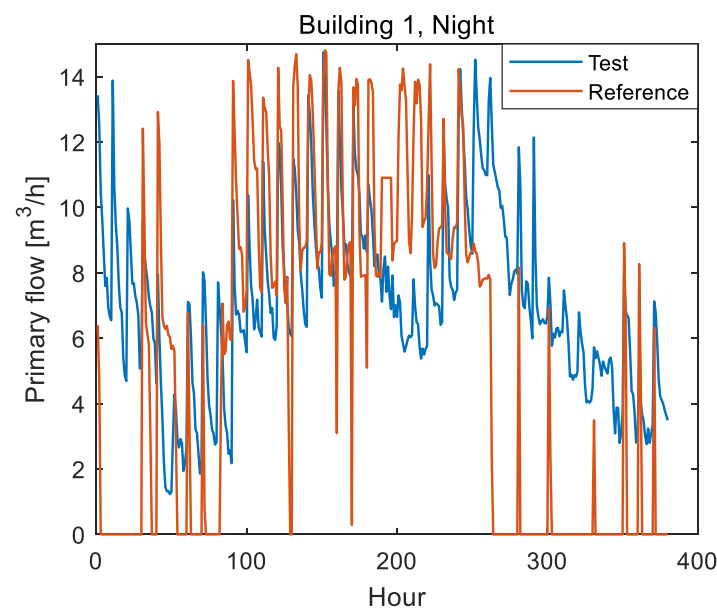

Figure 7. Primary chilled water flow for building 1 during the night for test and reference periods. The night is defined as the hours between 19:00 and 04:59.
Other incentives to encourage building owners to reduce the daytime cooling power could also be to redesign the price model and its components according to on and off-peak charges. However, this incentive is less directed to the specific usage of active night cooling but motivates action in several possible ways.

\section{Conclusion}

In this study, a field test of active night cooling in three commercial buildings with hydronic cooling systems supplied by district cooling was conducted during the summer of 2020 . The active night cooling strategy was tested during the first half of the summer and the second half was used as the reference period. The active night cooling strategy was implemented in a simple way, by changing the time schedule operation of the buildings' control systems during the active night cooling test and changing back to regular time schedules during the reference period.

The active night cooling control strategy did not succeed in reducing the hourly maximum cooling power, but the 100 hours with peak cooling load was reduced with $6.5 \%$ for one of the buildings. As expected, the total cooling energy usage increased between 1.7 and 5.3\% with active night cooling. However, the daytime energy usage was 0.7 to $4.6 \%$ lower for two of the buildings. Another noteworthy result was the morning peak cooling power reduction of $41 \%$, achieved with active night cooling for one of the buildings when the outdoor temperature was less than $15^{\circ} \mathrm{C}$.

It was also shown that the active night cooling control strategy did not result in indoor air temperatures lower than $20{ }^{\circ} \mathrm{C}$, although for one of the buildings the indoor air temperature was on average $1.2^{\circ} \mathrm{C}$ lower with active night cooling when the outdoor temperature was $\geq 22^{\circ} \mathrm{C}$, compared to the reference period. To compensate the building owners for the increased energy and primary flow costs with active night cooling, the economic incentives could be an energy price discount of $23 \%$ and a flow rate price discount of $19 \%$.

This field test showed that buildings with passive chilled beam systems were more promising for peak cooling load reductions than the building with active chilled beams as well as some cooling power and energy reductions can be achieved with simple measures. Lastly, it demonstrated the necessity of having sufficient knowledge about the district cooling customers' buildings and HVAC systems to evaluate incentives which encourage adjustments of the district cooling usage. This study provides a foundation for further research and optimization of active night cooling in buildings with hydronic cooling systems supplied by district cooling.

The authors would like to thank the property owner Vasakronan $\mathrm{AB}$ and the utility company Göteborg Energi $\mathrm{AB}$ for facilitating this study, and for support and valuable input. 


\section{References}

[1] IEA, "The Future of Cooling: Opportunities for energy-efficient air conditioning," Paris, 2018.

[2] S. Frederiksen and S. Werner, District Heating and Cooling. Studentlitteratur AB, 2014.

[3] A. A. Olama, District Cooling: Theory and Practice. Boca Raton, FL: CRC Press, 2017.

[4] E. Guelpa and V. Verda, "Thermal energy storage in district heating and cooling systems : A review," Applied Energy, vol. 252, no. March, p. 113474, 2019.

[5] K. M. Powell, W. J. Cole, U. F. Ekarika, and T. F. Edgar, "Optimal chiller loading in a district cooling system with thermal energy storage," Energy, vol. 50, no. 1, pp. 445-453, 2013.

[6] F. Souayfane, F. Fardoun, and P. Biwole, "Phase change materials ( PCM ) for cooling applications in buildings : A review," vol. 129, pp. 396-431, 2016.

[7] J. Feng, S. Schiavon, and F. Bauman, "Cooling load differences between radiant and air systems," Energy and Buildings, vol. 65, pp. 310-321, 2013.

[8] R. Hu, G. Liu, and J. Niu, "The Impacts of a Building's Thermal Mass on the Cooling Load of a Radiant System under Various Typical Climates," Energies, 2020.

[9] P. Sprecher, O. Böck, B. Gasser, and P. Kofoed, "Control strategy for cooled ceiling panels," ASHRAE Transactions, pp. 711-716.

[10] J. E. Braun, "Load control using building thermal mass," Journal of Solar Energy Engineering, Transactions of the ASME, vol. 125, no. 3, pp. 292-301, 2003.

[11] O. Seppänen, "Ventilation Strategies for Good Indoor Air Quality and Energy Efficiency," International Journal of Ventilation, vol. 6, no. 4, pp. 297-306, 2016.

[12] K. H. Yang, R. L. Hwang, and S. T. Tu, "The duty cycle air-conditioning operation and its energy impact evaluation on buildings," SAE Technical Papers, 1992.

[13] N. Kahled and M. Krarti, "Impact of precooling control on reducing electrical peak demand for commercial buildings in Tuniisia," in Proceedings of ES2007, 2007, pp. 565-572.

[14] A. Rabl and L. K. Norford, "Peak load reduction by preconditioning buildings at night," International Journal of Energy Research, vol. 15, no. 9, pp. 781-798, 1991.

[15] I. Andersen and M. J. Brandemuehl, "Heat storage in building thermal mass: a parametric study," ASHRAE Transactions, vol. 98, pp. 910 918, 1992.

[16] J. E. Braun, K. W. Montgomery, and N. Chaturvedi, "Evaluating the performance of building thermal mass control strategies," ASHRAE Transactions, vol. 108, no. pt 1, 2002.

[17] K. Keeney and J. Braun, "A simplified method for determining optimal cooling control strategies for thermal storage in building mass,"
HVAC and R Research, vol. 2, no. 1, pp. 59-78, 1996.

[18] G. P. Henze, J. Pfafferott, S. Herkel, and C. Felsmann, "Impact of adaptive comfort criteria and heat waves on optimal building thermal mass control," Energy and Buildings, vol. 39, no. 2, pp. 221-235, 2007.

[19] F. B. Morris, J. E. Braun, and S. J. Treado, "Experimental and simulated performance of optimal control of building thermal storage," ASHRAE Transactions, vol. 100, no. 1. pp. 402414, 1994.

[20] K. H. Lee and J. E. Braun, "Reducing peak cooling loads through model-based control of zone temperature setpoints," Proceedings of the American Control Conference, pp. 5070-5075, 2007.

[21] J. W. Andrews, M. Piraino, and J. Strasser, "Laboratory testing of control strategies to reduce peak air-conditioning loads," ASHRAE Transactions, vol. 99, no. pt 1. pp. 518-528, 1993.

[22] J. P. Conniff, "Strategies for reducing peak airconditioning loads by using heat storage in the building structure," ASHRAE Transactions, no. pt 1, pp. 704-709, 1991.

[23] M. D. Ruud, J. W. Mitchell, and S. A. Klein, "Use of building thermal mass to offset cooling loads," ASHRAE Transactions, no. pt 2. pp. 820829, 1990.

[24] S. Morgan and M. Krarti, "Field testing of optimal controls of passive and active thermal storage," ASHRAE Transactions, pp. 134-145, 2010.

[25] K. R. Keeney and J. E. Braun, “Application of building precooling to reduce peak cooling requirements," ASHRAE Transactions, vol. 103, no. 1. pp. 463-469, 1997.

[26] J. E. Braun, T. M. Lawrence, C. Klaassen, J. M. House, and I. E. Center, "Demonstration of load shifting and peak load reduction with control of building thermal mass," 2002 ACEEE Buildings, vol. 3, pp. 55-68, 2002.

[27] K. H. Lee and J. E. Braun, “An experimental evaluation of demand limiting using building thermal mass in a small commercial building," ASHRAE Transactions, vol. 112 PART 1, no. 2002, pp. 559-571, 2006.

[28] E. Solgi, Z. Hamedani, R. Fernando, H. Skates, and N. E. Orji, "A literature review of night ventilation strategies in buildings," Energy and Buildings, vol. 173, pp. 337-352, 2018.

[29] A. Larsson, "Night cooling optimization using post processed control systems data," 2015.

[30] J. Pfafferott, S. Herkel, and M. Jäschke, "Design of passive cooling by night ventilation: Evaluation of a parametric model and building simulation with measurements," Energy and Buildings, vol. 35, no. 11, pp. 1129-1143, 2003.

[31] J. Hu and P. Karava, "Modeling and analysis for mixed-mode cooling of buildings," ASHRAE Transactions, vol. 118, no. PART 2. pp. 308- 
315, 2012.

[32] J. E. Braun, "Reducing energy costs and peak electrical demand through optimal control of building thermal storage," ASHRAE Journal, vol. 96, no. Pt. 2, pp. 876-888, 6902.

[33] M. Kolokotroni and A. Aronis, "Cooling-energy reduction in air-conditioned offices by using night ventilation," Applied Energy, vol. 63, no. 4, pp. 241-253, 1999.

[34] A. Werner and R. Jonsson, Optimerad användning av fjärrkyla (Optimized utilization of district cooling). Svensk Fjärrvärme AB, 2012. 